Meta

Journal des traducteurs

Translators' Journal

\title{
Ideological Aspects of Translating News Headlines from English to Persian
}

\author{
Alireza Khanjan, Mohammad Amouzadeh, Abbas Eslami Rasekh et \\ Manoochehr Tavangar
}

Volume 58, numéro 1, avril 2013

URI : https://id.erudit.org/iderudit/1023811ar

DOI : https://doi.org/10.7202/1023811ar

Aller au sommaire du numéro

Éditeur(s)

Les Presses de l’Université de Montréal

ISSN

0026-0452 (imprimé)

1492-1421 (numérique)

Découvrir la revue

Citer cet article

Khanjan, A., Amouzadeh, M., Eslami Rasekh, A. \& Tavangar, M. (2013).

Ideological Aspects of Translating News Headlines from English to Persian.

Meta, 58(1), 87-102. https://doi.org/10.7202/1023811ar
Résumé de l'article

Le présent article qui est rédigé à la lumière de l'approche sociocognitive de Teun van Dijk, tente d'examiner quelques-unes des dimensions idéologiques de la traduction des titres dans la presse d'actualité de l'anglais en persan. Un certain nombre de titres parallèles en anglais et en persan ont été sélectionnés pour une analyse comparative et contrastive, avec notamment pour objectif de mettre en évidence différents outils idéologiques impliqués dans le processus de la traduction des titres. L'analyse qualitative des données modèles suggère que la polarisation des caractéristiques de " nous » contre " eux " est généralement influencée par l'approbation ou la désapprobation des traducteurs ou producteurs des textes d'actualité « cibles » du contenu idéologique de la une des journaux en question, et qui est représentée par le maintien, la modification ou la suppression d'éléments des textes sources dans les textes cibles. Ces stratégies de traduction se servent généralement d'expressions linguistiques (tant au niveau lexical que grammatical) ou d'éléments non linguistiques (tels que des images, des photos et des dessins).
Ce document est protégé par la loi sur le droit d'auteur. L'utilisation des services d’Érudit (y compris la reproduction) est assujettie à sa politique d'utilisation que vous pouvez consulter en ligne.

https://apropos.erudit.org/fr/usagers/politique-dutilisation/ 


\title{
Ideological Aspects of Translating News Headlines from English to Persian
}

\author{
ALIREZA KHANJAN \\ University of Isfahan, Isfahan, Iran \\ alirezakhanjan@gmail.com
}

MOHAMMAD AMOUZADEH

University of Isfahan, Isfahan, Iran

amouzadeh@fgn.ui.ac.ir

\author{
ABBAS ESLAMI RASEKH \\ University of Isfahan, Isfahan, Iran \\ abbasseslamirasekh@yahoo.com
}

MANOOCHEHR TAVANGAR

University of Isfahan, Isfahan, Iran

framesht2004@yahoo.co.uk

\section{RÉSUMÉ}

Le présent article qui est rédigé à la lumière de l'approche sociocognitive de Teun van Dijk, tente d'examiner quelques-unes des dimensions idéologiques de la traduction des titres dans la presse d'actualité de l'anglais en persan. Un certain nombre de titres parallèles en anglais et en persan ont été sélectionnés pour une analyse comparative et contrastive, avec notamment pour objectif de mettre en évidence différents outils idéologiques impliqués dans le processus de la traduction des titres. L'analyse qualitative des données modèles suggère que la polarisation des caractéristiques de «nous» contre «eux» est généralement influencée par l'approbation ou la désapprobation des traducteurs ou producteurs des textes d'actualité «cibles» du contenu idéologique de la une des journaux en question, et qui est représentée par le maintien, la modification ou la suppression d'éléments des textes sources dans les textes cibles. Ces stratégies de traduction se servent généralement d'expressions linguistiques (tant au niveau lexical que grammatical) ou d'éléments non linguistiques (tels que des images, des photos et des dessins).

\begin{abstract}
Drawing on Teun van Dijk's socio-cognitive approach, the present paper attempts to investigate certain ideological aspects of news headlining in an English-Persian translation context. A number of parallel news headlines have been chosen for contrastive analysis, with a view to highlighting the different ideological apparatuses involved in the process of translation of news headlines. A qualitative analysis of the sample data suggests that the polarization of us and them is generally influenced by translators'/target news producers' (dis)approval of the ideological content of the source headlines in question, and is represented through maintaining, manipulating or excluding original headlines in the target news stories. These translation strategies are typically realized through the purposeful application of linguistic expressions (both at lexical and grammatical levels) or non-linguistic elements (such as images, photos and graphic drawings).
\end{abstract}

\section{MOTS-CLÉS/KEYWORDS}

traduction, idéologie, polarisation eux/nous, analyse du disours critique, modèle sociocognitif

translation, ideology, us/them polarization, critical discourse analysis (CDA), sociocognitive model 


\section{Introduction}

Throughout the process of translation, a translator is consistently surrounded by various ideologies affecting his/her choices: the source author's ideology, the publisher's ideology, the target readers' ideological preferences and expectations, and his/ her own worldview. Each of these ideologies exerts a different level of pressure on the translator and may in turn lead him/her to adopt certain translation strategies (Al-Shehari 2007: 3). This is typically the case with inherently ideological environments such as news agencies, where translators are generally forced to follow the publishers' policies and ideological stances and are frequently monitored by revisers, section editors or editors-in-chief (Al-Shehari 2007: 3). Throughout the news translation process, equivalence relations ${ }^{1}$ are sometimes totally lost so that one may find it difficult to realize if the target text in question is the translation of a single source text, or whether it consists of a set of information derived from different sources (Al-Shehari 2007: 3).

News stories are not typically signed by a single journalist (Bani 2006: 36) and, accordingly, there is always the possibility of ideological interference with the content of the news materials to be translated. Hajmohammadi describes the working conditions governing news translation in the Iranian news agencies, and clearly states that these agencies may well call for some deviation from the source text content on the basis of their ideological policies, and that such a treatment is justified in terms of "current ethics" (Hajmohammadi 2005: 215). Bakhshandeh and Mosallnejad (2005) also have observed that the translators working at the Iranian news agencies are frequently asked to function as journalists in their own rights and that, in so doing, they have to make changes in the form and rhetoric of the news stories in order to persuade their editors to publish the resulting texts. In general, as Vuorinen (1995, cited by Bani 2006: 38) maintains, throughout the translation process, which starts from the selection of sources and ends with the readers' reactions to the translated text, there is a series of gatekeepers controlling the information flow.

Bearing in mind such considerations, we have tried to adopt a critical discourse analysis (CDA) framework, namely Teun van Dijk's socio-cognitive approach (van Dijk 1988; 1995; 1998a; 1998b; 2008) to explore the ideological polarizations of us and them in an English-Persian news headline translation context.

\section{Review of literature}

A brief review of current research literature indicates that news headlines have not received due attention in the field of translation studies (Al-Shehari 2007: 11). This situation is even true of news stories in general. Apart from the domain of machine translation, in which there is an increasing tendency to work on how to develop software tools for on-line translation of news headlines (see, for example, Saha and Bandyopadhyay 2005, Ali 2010, Wubben, van den Bisch and Krahmer 2010), there is a remarkable vacuum in the domain of news headlines translation. More specifically, while CDA approaches to media discourse date back to several decades ago, it is striking to see that translation scholars have not taken sufficient heed of the application of CDA to the area of translation of news, in general, and of news headlines, in particular.

As for the translation of news headlines, the research gap may be attributed to the fact that headlines are not typically taken as being separate from the main news 
stories and, accordingly, their analysis is not assumed to be divorced from that of their relevant texts. However, news headlines in general, and headlines appearing in the newspapers, in particular, have the highest readership (Khodabandeh 2007: 92), though in many cases, the readers may confine themselves to having a quick scanning of news titles displayed on the counter of news dealers or on the on-line news pages, mostly without reading their main texts. Therefore, it would be advisable to analyze news headlines (and their translations) as independent textual products since, as implied above, they have the potential of playing independent roles of their own.

Our attempts to bring to light relevant research on the topic under discussion have made it clear that there happens to be only a handful of papers available. Sidiropoulou (1995) has compared the translations of news headlines in the Greek press with their English originals; Kuo and Nakamura (2005) have investigated, within a CDA-based case study, the news headlines of two English news stories translated into Chinese published by two different Taiwanese newspapers with competing ideological stances; Montgomery (2006) has adopted Jakobson's concept of intralingual translation (Jakobson 1959) to address the transfer of expressions from one domain of the public sphere, such as presidential speeches or broadcast interviews, to another domain, such as newspaper headlines. In a similar vein, Valdeón (2007) has attempted to analyze the ways in which translational processes have an effect on the informative and persuasive functions of news headlines with regard to the target language readership. Finally, Al-Shehari (2007) has tried to investigate the strategies adopted by Aljazeera news network in its English translation of the news stories published originally in Arabic. His aim is to explore how certain ideologies can be conveyed semiotically through the translation of news headlines.

The findings of the above research works can be summarized as follows:

1) The translation of news headlines is sometimes subject to ideological manipulation;

2) Ideological elements emerging in translated news headlines sometimes result from the rhetorical macro-structure of news headlines in the source languages involved;

3) Ideological interferences with the news headline translation are mostly conscious; and finally

4) Target readers' ideological expectations may affect the skopus and strategies of news headlining in translation.

\section{Theoretical framework: van Dijk's socio-cognitive model}

According to van Dijk (1998c), critical discourse analysis (CDA) is a field that is concerned with studying and analyzing written and spoken texts to reveal the discursive sources of power, dominance, inequality and bias. It examines how these discursive sources are maintained and reproduced within specific social, political and historical contexts.

Van Dijk's socio-cognitive model not only takes into account grammatical, phonological, morphological and semantic micro-structures, but also deals with some "higher level properties" such as the local coherence, overall themes, news topics, schematic structures and rhetorical dimensions of texts. He is attentive to the "production processes" including journalistic and institutional practices of newsmaking as well as the economic and social practices involved in the creation of media discourse and, at the same time, he pays attention to the "reception processes" including the comprehension, memorization, and reproduction of news information (van 
Dijk 1988: 2). Moreover, through the analysis of the macrostructure of news stories, van Dijk explores the thematic and schematic structures of news texts.

Van Dijk (1995) basically perceives discourse analysis as a kind of ideology analysis because, according to him, "ideologies are typically, though not exclusively, expressed and reproduced in discourse and communication including non-verbal semiotic messages, such as pictures, photographs and movies" (van Dijk 1995: 17). Van Dijk's ideology analysis consists of a triangle of society, discourse and cognition (van Dijk 1995: 30). While social analysis pertains to examining the "overall societal structures" (i.e., the contexts), discourse analysis is basically text-oriented (syntax, lexicon, local semantics, topics, schematic structures, etc.). What differentiates van Dijk's model from all other CDA approaches is its cognitive component. For him, it is the socio-cognitive aspect of discourse consisting of social and personal cognition that mediates between society and discourse (van Dijk 2008: 126). In a sense, van Dijk adopts a cognitive viewpoint when he defines ideology as "the overall, abstract mental systems that organize [...] socially shared attitudes" (van Dijk 1995: 18). Ideologies, thus, "indirectly influence the personal cognition of group members" in their act of comprehension of discourse among other social actions and interactions (van Dijk 1995: 19). By discourse, he means "(spoken and written) verbal structures and any semiotic (interpretable) aspect of the communicative event that directly sustains the event, such as relevant sound structures and visual (writing, print) structures, face work and gestures" (van Dijk 2008: 117).

Unlike such social science scholars as Engels and Gramshi, who adopt a Marxist definition of ideology as "false consciousness" (Vincent 2010: 6), van Dijk presents a more neutral definition whereby ideology can be either positive or negative. He borrows the term belief from psychology to present a general impression of ideology as the "system of beliefs" (van Dijk 1998a: 4). Thus, for van Dijk, ideology, in its negative sense, can be taken as a mechanism for legitimizing the dominance (such as the dominating ideology in totalitarian systems), while, in its positive sense, it may be used as legitimizing the resistance against dominance and social inequalities (such as the anti-racist ideology) (van Dijk 1998a: 5).

Van Dijk labels the individuals' mental representations involved in social actions and interactions as "mental models"; models which specify the individual's actions, speech and writing and characterize the way s/he perceives others' social interactions (van Dijk 1995: 2). He believes that mental representations "are often articulated along us versus them dimensions, in which speakers of one group generally tend to present themselves or their group in positive terms, and other groups in negative terms" (van Dijk 1995: 22). He also states that an analyst who desires to make such an ideological dichotomy transparent needs to analyze discourse in the following way (van Dijk 1998b: 61-63):

a) Examining the context of the discourse (historical, political or social background of ideological oppositions and their main participants);

b) Identifying groups, power relations and ideological conflicts involved;

c) Identifying positive and negative opinions about us versus them;

d) Making explicit the presupposed and the implied; and

e) Examining all formal structures involved (lexical choices and syntactic structures, in a way that helps to (de)emphasize polarized group opinions. 
Analyzing and making explicit the contrastive polarization of $u s$ and them, as described above, has been central to most of van Dijk's works $(1988,1995,1998$ a, 1998b). The concept of "ideological square" (van Dijk 1998b) which is related to this kind of polarization designates the following dimensions:

1) Emphasizing our positive actions or properties;

2) Mitigating their positive actions or properties;

3) Emphasizing their negative actions or properties;

4) Mitigating our negative actions or properties.

TABLE 1

Van Dijk's Ideological Square: Polarization of $U s$ and Them

\begin{tabular}{|l|l|l|}
\hline & \multicolumn{1}{|c|}{ Us } & \multicolumn{1}{c|}{ Them } \\
\hline Emphasizing & Positive Properties /Actions & Negative Properties /Actions \\
\hline Mitigating & Negative Properties /Actions & Positive Properties /Actions \\
\hline
\end{tabular}

\section{The structure and features of news headlines}

A news story starts with a headline, a line appearing on top of it, which says to the reader what the news is about (Bakhshandeh and Mosallanejad 2005: 29). A news headline typically shaped around a phrase or a sentence leads the reader towards the news content and represents the essence of the news in question. It can persuade the reader to read the text or ignore it (Badii and Ghandi 2004: 108). Chen Xu (2009: 2) has presented a working definition of news headline which is in line with the aims of the present paper: "A headline is a line of concise words outside a newspaper story or article, usually printed in various types and devised to summarize and make comments on the news content." Clearly enough, "summarizing" the content and "commenting" on it are both potentially capable of carrying ideological implications.

News headlines are usually written on the basis of the main points of the story by, or under the supervision of, an editor and are sometimes regarded as the hardest task of journalistic writing (Bakhshandeh and Mosallanejad 2005: 29). Readers often scan news titles and choose among them the desirable materials on the basis of their attractions or relevance to their own ways of living or thinking.

If we bear in mind the significance of news headlines in evaluating and prioritizing news events, they are assumed to reflect as exactly, briefly and clearly as possible the most important points of the story. From a journalistic point of view, a news headline should possibly conform to the lead ${ }^{3}$ component of the story and thus express the lead content concisely (Badii and Ghandi 2004: 109). In some cases (see Table 2 for an example), the news headline consists of certain sub-parts including the kicker, the main headline and the deck (Badii and Ghandi 2004: 111-114).

TABLE 2

Headline sub-parts

\begin{tabular}{|l|l|}
\hline kicker & Zidane: \\
\hline main headline & Italy Doomed to Failure \\
\hline deck & FIFA World Cup Final Tomorrow \\
\hline
\end{tabular}


The most arresting sub-part is the main headline referring to the most important point of the news story. In most news headlines, this is the only obligatory component but, if this is not the case, it is to be printed in bold type to be differentiated from subtitles and kickers.

\section{The data and method}

In parallel with the major trend in $\mathrm{CDA}$, the present paper adopts a purely qualitative analysis approach. A series of data consisting of English news headlines with their parallel Persian translations published in the Iranian media or news agencies were gathered and compared to analyze the ways in which our and their properties and actions are polarized. With the topic in mind, the data were chosen by a self-selection process. The rationale behind such a procedure rests on the very nature of retrospective research, which is typically assumed to look back to explore pre-existing variables (Delavar 1999: 393). For the sake of narrowing down the research scope and observing the space limit of the paper, the investigation of a limited number of examples (i.e., 6 cases out of some 50 news headlines) would be sufficient and adequate for substantiating our arguments. ${ }^{4}$ While the first two sets of data deal with the global image of the U.S.A., the next four sets of data are concerned with the issue of the Iranian nuclear program. To ensure that the texts in question are parallel, ${ }^{5}$ we have resorted to those data sets in which the Persian news story has clearly mentioned the source of the original English news so that it is possible to compare the two texts to see if the target text has been derived from the source one. Moreover, since news headlines are sometimes combined with visual elements to convey certain ideological stances, such non-linguistic elements have been accounted for so that the analysis of what is "within" the text may accompany the analysis of paralinguistic elements "around" it.

\section{Analysis of sample data}

The first example consists of not only the headline of a news story published by the Foreign Policy Journal as a reaction to the dismissal of two American journalists (one being fired for his comments on Israel, the other for his opinion about the death of Seyed Mohamamd Hossein Fazlollah, a Lebanese religious leader) (Example [1a]) but also its Persian translation published by the Fars news agency on its official website (Example [1b]).

(1) a. The Dangerous Future of Journalism in America

(DePetris 17 July 2010)

b.

$$
\text { آينده خطرناك زورناليسم در آمريكا }
$$

[The dangerous future of journalism in America]

$$
\text { (Fars News Agency } 24 \text { July 2010) } 7
$$

Although the target headline has been produced by an official state-owned Iranian news agency, where the predominant ideology opposes the formal ideology governing the United States, the source headline has been literally rendered into the target language. This transfer can be interpreted as emphasizing their negative properties/actions (those of the government of the U.S.). Immediately after headlining, 
the translator/target news producer ignores the source lead component containing the very cases of the journalists in question altogether; rather, s/he selects part of the source news main body (Example [2a]) and translates it literally in the lead component of the target news to re-emphasize negative properties/actions of the American government (Example [2b]):

(2) a. [...]in the $21^{\text {st }}$ century, the U.S. is an uptight and hypersensitive nation that chastises any comment detached from official U.S. policy.

(DePetris 17 July 2010; see note 6)

b.

$$
\text { واشنكتن راين كشور، در قرن بيست و يكم، هر گَونه اظهار نظر بر خلاف سياست رسمى }
$$

[The government of this country, in the $21^{\text {st }}$ century, chastises any comment detached from Washington's official policy.]

(Fars News Agency 24 July 2010; see note 7)

The extraction of the above Persian section transferred from the source news body to the lead component of the target text has apparently been intended to emphasize negative properties of the rival ideology, especially because the translator/TT producer combines the target headline and lead components with a graphic image of Liberty Statue being shaded darkly against an illusionary, ambiguous background ${ }^{8}$ in contrast to its familiar and clear flame which has been replaced by a sinisterlooking radiant spark. The combination of this graphic component with the headline and the lead following it results in a shift from the speech act ${ }^{9}$ intended by the headline. While the ST author "warns" that the dismissal of journalists who write their stories in opposition to the U.S. government's official viewpoint may become a consistent trend in near future, the combination of the target headline and the lead component, along with the graphic accompanying them, "informs" the reader that this is what has already happened and that it is too late to warn about it. So the TT implies that the freedom of expression in the American society is no longer a reality and that there is no clear, hopeful perspective for it (emphasizing their negative properties/actions). To sum up, the above sample shows that maintaining the form and content of the source headline in the target news story does not necessarily imply the translator's ideological agreement with the ST producer, but that this strategy ${ }^{10}$ may in turn be ideologically laden.

In Examples (3) and (4), we also observe the translators'/TT producers' faithfulness to the form and content of the source news headline:

(3) a. Bill Clinton: U.S. should be prepared to lose global dominance

(Voltaire Network 2 October 2010) $^{11}$

b.

بيل كلينتون: آمريكا بايد آماده از دست دادن سلطه جهانى خود باشد.

[Bill Clinton: America should be prepared to lose its global dominance]

(Fars News Agency 7 October 2010)12

The source English news was published on October 2, 2010 on Voltaire Network news website. The author has reported the highlights of Clinton's speech given at Yalta European Strategy (YES) annual meeting. The news story was translated by Fars News Agency a few days later. As in Example (1), for the same reasons, the strategy adopted by the translator/TT producer in being faithful to the source headline 
can again be interpreted as emphasizing their negative properties (of the U.S.). Again, the translator/TT producer has highlighted a part of the source news body as the target news lead to re-emphasize the content of the source news headline (foregrounding their negative properties):

(4) a. Former U.S. President Bill Clinton believes that Washington must brace for loss of global domination in the face of rapidly developing economies like China and India.

(Voltaire Network 2 October 2010; see note 11)

b.

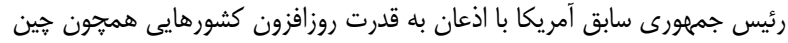

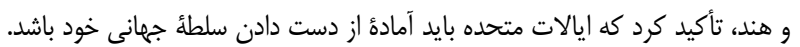

[America's former President, admitting the increasing power of countries like China and India, emphasized that the United States should be ready to lose its global dominance.]

(Fars News Agency 7 October 2010; see note 12)

The combination of the Persian news headline (Example [3b]) and its following lead (Example [4b]) compels us to conclude that a translator/TT producer may polarize $u s$ and them through making some selective changes in the order of source news story components by transferring some elements from the news body to the lead or from the lead to the headline, or by doing vice versa. A selective treatment is also shown in Example (4), as the phrase "economies like China and India" is replaced by "كشورهايى همجِون خين و هند" [countries like China and India] in which the content of the source headline and that of the original news story have been distorted ideologically. While Clinton foresees that the United States will lose its "economic dominance," the target lead emphasizes the loss of "political dominance" of the U.S. in future.

Example (5) refers to a news headline published by Irish Times news website regarding the comments made by Dmitry Medvedev, the former Russian President, on the Iranian nuclear program. It has been translated into Persian by Mehr, an Iranian news agency:

(5) a. Russia calls for Iran "explanation"

(Irish Times Breaking News Word 15 July 2010) ${ }^{13}$

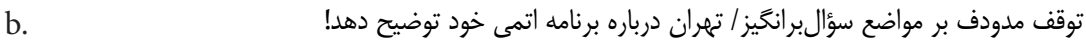
[Medvedev pauses on questionable stances: Tehran [should] explain about its nuclear program!]

(Mehr 16 July 2010) $)^{14}$

While the English headline consists of only one main title, its Persian translation includes a kicker and a main headline. The English headline is more or less parallel to the Persian main title but the overall content of the main headline has been questioned in the kicker. The source headline indicates that Russia asks Iran to explain about its nuclear program frequently regarded as non-peaceful by some countries. The Iranian government and the Iranian media have always denied any nuclear arms ambitions by reacting to other countries' aggressive stances, and the above Persian headline is not an exception to this general rule. The kicker added to the main title directly criticizes Medvedev's attitude towards the Iranian nuclear program. On the one hand, the translator/TT producer has explicitly mentioned the name of the actor 
involved in the comment stated in the headline (i.e., Dmitry Medvedev) instead of using the impersonalized word "Russia" (a strategy, called personalization by van Leeuwen 2008) in order to imply that the comment made by that particular person is nothing but a personal attitude and therefore cannot be generalized to the Russian government's overall position (mitigating what is regarded as negative for $u s$ ). On the other hand, the translator/TT producer has resorted to a certain strategy being already labeled as meta-opinion by van Dijk (1998b), to question Medvedev's doubts about the Iranian nuclear program. This strategy is intended to emphasize what is regarded by us (the Iranian government) to be the other's (Medvedev's) negative action. Meta-opinions, in van Dijk's terminology (1998b: 59), are "opinions about opinions" and typically include subjective comments on others' opinions in order to cast doubts on the validity of such attitudes. In Example (5), the translator/TT producer has expressed his meta-opinion with an exclamation mark (!).

As for the Persian main title, there remains a point to be further spelled out. Despite the fact that the source news headline producer has employed a declarative mood to convey Russia's call for Iran's explanation, the translator/TT producer has used the imperative mood resulting in the conversion of the speech act from "informing" to "commanding" in order to reinforce Medvedev's aggressive stance (emphasizing their negative properties/actions).

Let us now take a similar data set, again on the topic of the Iranian nuclear program, in which the target headline has totally departed from the source title, so that the result can no longer be regarded as a translation but, rather, a version, to use House's terminology (2009: 119). ${ }^{15}$ Example (6a) is the headline of a news story written by Exman and Faulconbridge (14 May 2010) and published by Reuters regarding the Brazilian and Russian former Presidents' news conference at which Medvedev commented on da Silva's chances of finding a solution to the Iranian nuclear issue.

(6) a. Russia says Lula has poor chance of success in Iran

(Exman and Faulconbridge 14 May 2010) ${ }^{16}$

b. تيجه مذاكرات "لولا داسيلوا" و "ميدويديف": برزيل و روسيه هيج تمايلى بر تحريمهاى جديد عليه ايران ندارند [The result of negotiations between Lula da Silva and Medvedev:

Brazil and Russia are not absolutely willing to impose new sanctions against Iran]

(Fars News Agency 15 May 2010) ${ }^{17}$

The ST producer's pessimistic attitude towards da Silva's chances of success in Iran is apparently in line with Medvedev's position, and that is presumably why Reuters has selected this opinion as the main title. This ideological stance was immediately made explicit in the source news lead:

(7) Kremlin chief Dmitry Medvedev said on Friday the Brazilian president was unlikely to succeed in his last ditch attempt to prevent further sanctions against Iran by mediating with the Islamic Republic.

(Exman and Faulconbridge 14 May 2010; see note 16)

This ideological orientation, however, has not been accepted by the translator/ TT producer (and perhaps by many TT readers). Therefore, the TT producers have adopted the strategy of translation manipulation. ${ }^{18}$ The Persian headline published 
by the Fars News Agency on 15 May 2010 (Example [6b]), cannot, in any way, be regarded as a translation of the source headline. While the source title, without the read of the body of the news story, clearly reflects the Russian government's pessimism about the possible outcome of the Brazilian President's mediation between Iran and the six world powers, this pessimism, in the target title, has totally been replaced by optimism. The translator/TT producer has selected part of the source text (not from the news body but from the comments made by the Reuters' journalists) indicating Russian reluctance towards new sanctions against Iran (Example [8]) and has highlighted that part in the target news headline (Example [6b]):

(8) Like China, Russian leaders have been reluctant to support new punitive measures against Tehran until all other avenues are exhausted

(Exman and Faulconbridge 14 May 2010; see note 16)

By selecting the target title (Example [6b]), the TT producers have ignored the source title altogether and, in practice, they have resorted to a strategy named suppression (van Leeuwen 2008: 42). ${ }^{19}$ The polarization of us and them can easily be recognized in the target news headline. On the one hand, Medvedev's pessimism about da Silva's mission to persuade Iranian authorities is suppressed altogether and cannot be retrieved from the translated text (mitigating what is regarded as negative for $u s$ ) and, on the other hand, Medvedev's and his relevant government's reluctance to impose new sanctions on Iran has been transferred from the marginal parts of the source text to be highlighted in the target news headline (what is regarded as positive for $u s$ ). To use van Leeuwen's terms (van Leeuwen 2008), TT producers have resorted to the following manipulation strategies: association (the addition of the name of Brazil to the news headline as the country reluctant to impose new sanctions on Iran while there has been nothing in the source news text in this regard); the impersonalization of the social agents involved (in particular, the spatialization ${ }^{20}$ of Dimitry Medvedev's name into the impersonal name Russia in order to over-generalize his opinion to the entire country and doing the same with the name of da Silva and his country, Brazil); and finally, making use of the Persian quantifier "هيج" [nothing] in the target news headline in order to impress on the reader's mind the strong reluctance of both Brazilian and Russian governments to impose further sanctions on Iran.

Moreover, the Iranian national flag, on which a logo of nuclear energy has been depicted, appears on the web page of Fars News Agency associated with Example (6b). A graphic analysis of this flag clearly shows the TT producers' overall attitude towards the Iranian nuclear program: in the TT producers' opinion, nuclear energy has something to do with the Iranian national interests and, just like the components of the Iranian national flag, it should be taken as an inseparable part of the national reputation, dignity and solidarity. They believe that almost all Iranian citizens have the same opinion about the nuclear program and would refuse ignoring it (emphasizing our positive properties/actions).

Example (9) again deals with the Iranian nuclear program and the way western governments treat it. The English headline has been written by Symonds (5 July 2010) and published on Voltaire Network and its so-called Persian translation has appeared on the Fars News Agency website (1 August 2010): 
(9) a. Act of war

Harsh new US penalties against Iran

(Symonds 5 July 2010) ${ }^{21}$

b.

[An American journalist:

نويسندة آمريكايى: تحريم ايران منافع برخى كشورها را با خطر مواجه مىسازد.

Imposing sanctions on Iran will endanger some countries' interests.]

(Fars News Agency 1 August 2010)22

Peter Symonds, the source news story writer, uses the above headline to inform the reader of further severe sanctions to be imposed on Iran and its nuclear program. Immediately after the headline, within a long lead, Symonds comments on Obama's signing new laws extending sanctions against Iran on July 1, 2010 and interprets it as a severe action potentially capable of destroying the Iranian economy. In his opinion, "whereas the Obama administration calmly portrays economic sanctions as 'peaceful' solutions to political problems," signing a new law on further punitive measures against Iran can be equivalent to an act of war. So, he adds the kicker "act of war" (printed in the red color) to the main headline in order to reflect the severity of the new sanctions. The photograph inserted right after the source lead in which President Ahmadinejad is getting off an Iranian airplane at Mehrabad International Airport accompanies an extract of another news story published on the same date on recent problems of the Iranian airplanes with refueling in Germany, Britain and U.A.E. (emphasizing the severity of sanctions to be imposed on Iran).

In addition, the source news writer interprets the enactment of new punitive measures as Obama's killing several birds with the same stone and believes that the U.S. government aims at punishing both Iran and Washington's economic rivals in Europe and Asia and this is what the translator/TT producer extracts and foregrounds as the target headline. S/he has put aside the source news headline altogether (mitigating what is negative for $u s$ ) in order to dismiss the impact of new sanctions on Iran. S/he has gone even further by employing a graphic image, to claim that "تحريمهاى آمريكا عليه ايران" [sanctions imposed on Iran] would only damage the Americans themselves (emphasizing what is regarded as their negative actions).

The last data set includes an English news headline regarding the German Foreign Minister's comment on the Iranian willingness to return to the negotiations on its nuclear program. Written by Graham (8 October 2010) and published by Reuters, it was immediately translated into Persian by the Fars News Agency at the same date:

(10) a. Iran showing greater readiness to talk - Germany

(Graham 8 October 2010) ${ }^{23}$

b. برلين: ايران آماده كفت و گَوست ولى حاضر نيست امتيازى بدهد.

[Berlin: Iran is ready to talk but is not ready to give a concession.]

(Fars News Agency 8 October 2010) ${ }^{24}$

The above English phrase is the title of a news story written by Dave Graham on the talks between Guido Westerwelle, the German Foreign Minister, and Yukida Amano, director general of the International Atomic Energy Agency (IAEA). The stop of negotiations between Iran and the six world powers on the Iranian nuclear program has been the topic of the talks. There have already been some discussions 
about the possibility of the return of Iranian representatives to the negotiation table. In such a context, Westerwelle has talked about greater readiness of Iran (greater than before) to re-start the talks. The writer of the source news story repeats this point in the lead component wherein he mentions that in Westerwelle's opinion, Iran has not yet shown any willingness to make compromises:

(11) Iran is showing increased readiness to resume talks about its disputed nuclear programme but has not indicated any willingness to make compromises yet, German Foreign Minister Guido Westerwelle said on Friday.

(Graham 8 October 2010; see note 23)

This is exactly what the translator/TT producer has selected to highlight in the target news headline (10a).

The TT producers do apparently agree with the German Foreign Minister's comment in general but they have represented the details in the target headline in such a way that would result in the reinforcement of the stance already adopted by the Iranian government. The adjective "greater" has been omitted from the target headline in order to conceal that Iran has not been willing to return to negotiations (mitigating our negative properties/actions). In contrast, the translator/TT producer has shifted the transivity structure of the sentence by changing the material process of the verb نشان دادن [to show] into the existential process of the verb آماده بودن [be (ready)] in order to emphasize that Iran has already been prepared to come back to negotiations (emphasizing our positive properties/actions). The essential ideological conflict, however, emerges when the TT producers, as stated above, have stressed their attitude towards sustaining as strongly as possible their previous stances about Iran's right of exploiting nuclear energy. This attitude has been reflected through the ideologically oriented translation of a particular section of the source lead in the target headline indicating Iran's reluctance to make compromises:

$$
\begin{aligned}
& \text { وزير خارجه آلمان با اشاره به موضوع هستهاى ايران اعلام كرد كه ايران آماده مذاكره است ولى در موضع آن } \\
& \text { روى نداده است و اين كشور حاضر نيست امتيازى بدهد. }
\end{aligned}
$$

[German Foreign Minister mentions that Iran is ready to talk but has not made any changes in its stance and is not going to give any concessions.]

(Fars News Agency 8 October 2010; see note 24)

The source writer has made use of the word "compromise" but the TT producers have used the verb امتياز دادن [to give a concession]. This is a significant choice at the level of lexicon since the word مصالحه [compromise] presupposes that there must have been a مناقشه [dispute/quarrel] to be settled or compromised upon. This purposeful selection ${ }^{25}$ has been aimed at re-stressing that the Islamic Republic of Iran has never had any nuclear arms ambitions and that its nuclear program is by no means disputable. In addition, by making use of the lexical item امتياز ندادن [not to give a concession] (in future negotiations), the translator/TT producer has again insisted on the Iran's nuclear rights (emphasizing our positive properties). 


\section{Concluding remarks}

The present paper has aimed to explore the ideological polarization of $u s$ and them in the context of news headline translation within Teun van Dijk's socio-cognitive approach (1988; 1995; 1998a; 2008 and, in particular, 1998b). We began by introducing the topic under investigation followed by a brief account of some relevant literature. Then, we had a short introduction to the model adopted. In the next section, we talked about the structure and characteristics of news headlines and finally, we analyzed a number of examples extracted from the collected data based on the framework of "ideological square model" (van Dijk 1998b) in order to explore the ideological polarization of $u s$ and them.

The analysis of the translated headlines suggests the following points: the translators'/TT producers' approval of the ST producers' ideological stances typically results in equivalent target headlines although there are cases where the translators/ TT producers may use some additional linguistic elements in the form of kickers or lead components or resort to non-linguistic elements such as images, photographs or graphics in order to strengthen the ideological force of the translated headline. These strategies are not limited to cases of ideological transfer, but they may also be used in cases where we encounter the processes of ideological elimination or manipulation of the source headlines in the target texts. It is also true that the translators/ TT producers may change the order of a news story components to highlight a particular ideologically significant item being transferred from less important parts such as the main body to more important components such as the lead or the headline (or, rather, they may do otherwise) in order to polarize us and them.

In some cases of ideological disagreement, the translators/TT producers may be superficially faithful to the source headline content but, at the same time, cast doubts on its ideological stances by adding subjective comments to the components adjacent to the headline (i.e., kickers, decks, or graphic elements) through "meta-opinions" or through certain ideologically laden punctuation marks.

Furthermore, the ST/TT ideological disagreement, as can be expected, may lead to the elimination or manipulation of the source news headline in the target text. In such cases, the selected target headline may have nothing to do with the source title or it may be derived from the ideological translation of a less important part, thus raising it to the headline position.

The last point worth mentioning is that the translation strategies mentioned above do operate at both levels of lexicon and grammar. The analysis of the examples has indicated that there is a possibility of sentence mood conversion or transivity structure changes (i.e., changes in the verb processes involved). However, commenting on the type of grammatical structures which typically undergo manipulation in the process of news translation in general, and news headline translation in particular, would require analyzing a more comprehensive corpus and possibly, doing a more adequate statistical computation, which has simply been beyond the scope of this paper. 


\section{NOTES}

1. By equivalence we mean "the extent to which texts in different languages have the same meaning or effect” (House 2009: 116).

2. Van Dijk (1998b) does not actually define the two terms actions and properties but the way he employs them leads us to the conclusion that by actions he simply means "what we/they do" and by properties he means "what we/they are."

3. Immediately after a news headline, there might be an optional component called the lead of the news story. The lead gives the story its structure, and directs the reader to the rest of the story (Bakhshandeh and Mosallanejad 2005: 29).

4. The data gathered are limited to some 50 cases only, since, as far as our searching results on the web suggest, within the time span we have covered (i.e., the year 2010), there have been no more English news stories on the two topics under discussion with parallel texts published in Persian.

5. By a parallel text we mean a (source) text placed alongside its (target) translation(s) or version(s).

6. DePetris, Daniel R. (17 July 2010) The Dangerous Future of Journalism in America. Foreign Policy Journal. Visited on 15 January 2013, <http://www.foreignpolicyjournal.com/2010/07/17/thedangerous-future-of-journalism-in-america/ $>$.

7. Fars News Agency (24 July 2010 - 02 Mordâd 1389) آيندة خطرناك زورناليسم در آمر يكا future of journalism in America]. Visited on 15 January 2013, <http://www.farsnews.com/newstext. php?nn=8905020226>.

8. The background of the graphic image is in red; this color typically contributes to the ambiguity of the background (it may denote such concepts as troubled time, evil, fire, etc.).

9. The act implemented by making an utterance, e.g., ordering, requesting, promising, threatening, congratulating, or asserting is called as speech act (Bloor and Bloor 2007: 176). The speech act theory originated in the work of the philosopher Austin in the 1950s. He observed that, in certain contexts, utterances can perform illocutionary acts, and not simply report on facts or give information; we can use language to make a promise, give an instruction, name a ship, marry someone, make a bet, and so on (Bloor and Bloor 2007: 10).

10. "A strategy is $[\ldots]$ an action that aims to achieve a purpose [...] where: a) there is no certainty of success (i.e. it is not a mechanistic application of a rule), and b) there are viable alternative actions (i.e. other ways of aiming to achieve the same or similar purpose). (Pym 2011: 92-93)

11. Voltaire Network (2 October 2010): Bill Clinton: U.S. should be prepared to lose global dominance. (Translated by Luis MDAHUAR) Visited on 15 January 2013, <http://www.voltairenet.org/ article167149.html>.

12. FArs News Agency (7 October 2010 - 15 Mehr 1389): بيل كليتتون: آمريكا بايد آماده از دست دادن سلطان [Bill Clinton: America should be prepared to lose its global dominance]. Visited on 15 January 2013, <http://www.farsnews.com/newstext.php?nn=8907130469>.

13. Irish Times Breaking News Word (15 July 2010): Russia calls for Iran "explanation." Visited on 15 January 2013, <http://www.irishtimes.com/newspaper/breaking/2010/0715/breaking40.html>.

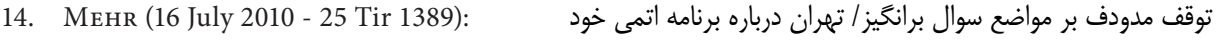
] توضيح دهد! program!] Visited on 15 January 2013, <http://old.mehrnews.com/fa/NewsDetail.aspx?NewsId= $1117407>$.

15. According to House, a version is an adaptation of the original text which is not a translation, i.e., there is no equivalence relation between the original and a version of it in another language (House 2009: 119).

16. Exman, Fernando and Faulconbridge, Guy (14 May 2010): Russia says Lula has poor chance of success in Iran. Reuters. Visited on 15 January 2013, <http://www.reuters.com/article/2010/05/14/ us-russia-brazil-iran-idUSTRE64D42Z20100514>.

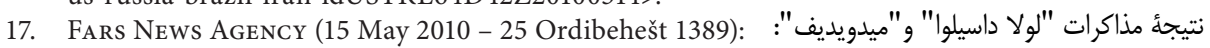
[The result of negotiations between Lula da Silva and Medvedev: Brazil and Russia are not absolutely willing to impose new sanctions against Iran]. Visited on 15 January 2013, <http://www.farsnews.net/newstext.php?nn=8902250231>.

18. Manipulation is a type of text handling on the part of the translator aimed at bringing a target text into line with a particular model and hence a particular correctness notion and in so doing secure(ing) social acceptance, even acclaim (Hermans 1985: 11, see also Dukāte 2009: 74).

19. Suppression is a sub-part of "exclusion" and refers to the irretrievable concealing of the agent(s) involved in the subject or the subject itself (van Leeuwen 2008: 42). 
20. Spatialization is a form of objectivation in which social actors are represented by means of reference to a place with which they are, in the given context, closely associated (van Leeuwen 2008: 46).

21. Symonds, Peter (5 July 2010): Act of war - Harsh new US penalties against Iran. Voltaire Network. Visited on 15 January 2013, <http://www.voltairenet.org/ article166183.html>.

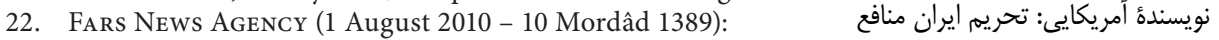
[An American journalist: Imposing sanctions on Iran will endanger some countries' interests]. Visited on 15 January 2013, <http://www.farsnews.com/ newstext.php?nn=8905091037>.

23. Graham, Dave (8 October 2010): Iran showing greater readiness to talk - Germany. Reuters.Visited on 15 January 2013, <http://af.reuters.com/article/worldNews/idAFTRE69710J20101008?sp=true>.

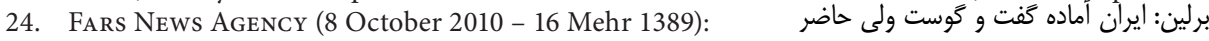
[Berlin: Iran is ready to talk but is not ready to give a concession.]. Visited on 15 January 2013, <http://www.farsnews.com/newstext.php?nn= 8907160916>.

25. In his article of 2007, Munday mentions that when using CDA, translation studies tends to jump to conclusion too quickly about the intentions of the translator (Munday 2007: 195-217). In the present paper, however, we have adopted the 'ideological square' model as our analytical approach in order to avoid being too quick in judging about the translators' intentions and to propose that any conscious or unconscious translation manipulation may well be attributed to a particular ideological orientation.

\section{REFERENCES}

Ali, Ghadya A. (2010): How Arab Journalists Translate English-Language Newspaper Headlines: Case Studies in Cross-Cultural Understanding. New York/Ceredigion: The Edwin Mellen Press.

Al-SheHARI, Khalid (2007): Semiotics and the translation of news headlines: Making an image of the other. Translation Studies in the New Millennium: An International Journal of Translation and Interpretation. 5:1-16.

BAdII, Naiim and GHANDI, Hossein (2004): ruznameh negari-ye novin [Modern Journalism]. Tehran: Allameh Tabataba'i University Press.

Bakhshandeh, Ehsan and Mosallanejad, Parviz (2005): Journalistic transcreation: a new approach. Translation Studies. 3(9):25-44.

BANI, Sara (2006): An analysis of press translation process. In: Kyle ConwAy and Susan Bassnett, eds. Translation in Global News (Proceedings of the conference held at the University of Warwick on 23 June 2006). Warwick: University of Warwick, 35-45.

Bloor, Meriel and Bloor, Thomas (2007): The Practice of Critical Discourse Analysis: An Introduction. London: Hodder Arnold.

Delavar, Ali (1998): mabani-ye nazari va amali-ye pazhuhesh dar olum-e ensani va ejtema'i [Theoretical and Practical Foundations of Research in Humanities and Social Science]. $3^{\text {rd }}$ ed. Tehran: entesharat-e rushd.

DukĀTe, Aiga (2009): Translation, Manipulation, and Interpreting. Frankfurt am Main: Peter Lang.

Hajmoнамmadi, Ali (2005): Translation evaluation in a news agency. Perspectives: Studies in Translatology. 13(3):215-224.

Hermans, Theo (1985): Introduction: Translation Studies and a new paradigm. In: Theo HerMANs, ed. The Manipulation of Literature: Studies in Literary Translation. London: Groom Helm, 7-15.

House, Juliane (2009): Translation. Oxford: Oxford University Press.

Jakobson, Roman (1959). On linguistic aspects of translation. In: Lawrence Venuti, ed. (2004): The Translation Studies Reader. London: Routledge, 138-145.

Khodabandeh, Farzaneh (2007): A contrastive analysis of English and Persian newspaper headlines. The Linguistics Journal. 2(1):91-127.

Kuo, Sai-Hua and Nakamura, Mari (2005): Translation or transformation? A case study of language and ideology in the Taiwanese press. Discourse and Society. 16(3):393-417. 
Montgomery, Martin (2006): Semantic asymmetry and “The War on Terror." In: Kyle Conway and Susan BAssnetT, eds. Translation in Global News (Proceedings of the conference held at the University of Warwick on 23 June 2006). Warwick: University of Warwick, 23-28.

Munday, Jeremy (2007): Translating ideology, a textual approach. The Translator. 13(2):195-217.

PyM, Anthony (2011): Translation research terms: a tentative glossary for moments of perplexity and dispute. In: Anthony Pyм, ed. Translation Research Projects 3. Tarragona: Intercultural Studies Group, 75-110.

Saha, Diganta and Bandyopadhyay, Sivaji (2005): A Semantics-based English-Bengali Ebmt System for translating News Headlines. In: Proceedings of the $10^{\text {th }}$ Machine Translation Summit (Phuket, 12-16 December 2005), 125-133.

Sidiropoulou, Maria (1995): Headlining in translation: English vs. Greek Press. Target. 7(2):285304.

VALDEÓN, Roberto A. (2007): Translating news from the inner circle: Improving regularity across languages. Quaderns: Revista de Traducció. 14:155-167.

Van DIJK, Teun (1988): News Analysis: Case Studies of International and National News in the Press. Hillsdale: Lawrence Erlbaum Associates.

VAN Dijk, Teun (1995): Discourse analysis as ideology analysis. In: Christina Schäffner and Anita L. Wenden, eds. Language and Peace. Dartmouth: Aldershot, 17-33.

VAN DijK, Teun (1998a): Introduction. In: Teun van Dijk. Ideology: A Multidisciplinary Approach. London: Sage, 1-14.

VAN DijK, Teun (1998b): Opinions and ideologies in the press. In: Allen Bell and Peter Garrett, eds. Approaches to Media Discourse. Oxford: Blackwell, 1-63.

VAN DijK, Teun (1998c): Critical Discourse Analysis. Visited on 9 December 2011, <http://www. hum.uva.nl/teun/cda.htm>.

Van Dijk, Teun (2008): Discourse and Context: A Socio-cognitive Approach. Cambridge: Cambridge University Press.

Van Leeuwen, Theo (2008): Representing social actors. In: Theo Van Leeuwen. Discourse and Practice: New Tools for Critical Discourse Analysis. Oxford/New York: Oxford University Press, 23-74.

Vincent, Andrew (2010): Modern Political Ideologies. $3^{\text {rd }}$ ed. West Sussex: Wiley-Blackwell.

Vuorinen, Erikka (1995): News translation as gatekeeping. In: Mary SNELL-Hornby, Zuzana Jettmarová and Klaus KaINDL, eds. Translation as Intercultural Communication, Amsterdam/Philadelphia: John Benjamins: 161-172.

Wubben, Sander, Van Den Bisch, Antel and Krahmer, Emiel (2010): Paraphrasing Headlines by Machine Translation: Sentential paraphrase acquisition and generation using Google News. In: Eline Westerhout, Thomas Markus, and Paola Monachesi, eds. Proceedings of the 20th Meeting of Computational Linguistics in the Netherlands. Utrecht: LOT, 169-183.

Xu, Chen (2009): On translation of the news headlines. Visited on 31 July 2010, <http://xinjiangar.seemejob.com/index.php/display/article/1431.htm>. 